\title{
Correction: PARK7 maintains the stemness of glioblastoma stem cells by stabilizing epidermal growth factor receptor variant III
}

Jeong-Yub Kim $\cdot$ Hee-Jin Kim $\cdot$ Chan-Woong Jung $\cdot$ Byung-II Choi $\cdot$ Dae-Hee Lee $(\mathbb{D} \cdot$ Myung-Jin Park $(\mathbb{D}$

Published online: 8 February 2021

(c) The Author(s), under exclusive licence to Springer Nature Limited 2021

Correction to: Oncogene

https://doi.org/10.1038/s41388-020-01543-1
Unfortunately, in the original published version the given name of Dae-Hee Lee was incorrect.

The original version was corrected. 